\title{
A RAMESSIDE STELA OF THE CHANTRESS TJAUTY - NEDJEM FROM HELIOPOLIS
}

\author{
Gehan ROSHDY ${ }^{1}$ and Khaled ABU AL-ELA ${ }^{2}$ \\ ${ }^{1}$ Faculty of Education, Ain Shams University \\ gihanroshdy509@outlook.com \\ ${ }^{2}$ Ministry of Tourism and Antiquities \\ kabualala@yahoo.com
}

\begin{abstract}
This article is devoted to the study and publication of the funerary stela of the female singer $t 3 w t y-n d m$, which was discovered in 2008 in Heliopolis near the tomb of Panehsi. It is currently preserved in Arab El-Hisn magazine at El-Matariya under the registration No. 4008. There are no traces of colours on the stela, despite it being in good state of preservation; As some details in the figures have not been executed, it is considered to be unfinished. The decoration of the stela is composed of two registers separated by a horizontal line; it shows the owner of the stela Tjauty- nedjem and other individuals worshipping the gods Osiris and $\mathrm{Mr}-\mathrm{Wr}$ who were worshipped in Heliopolis mostly. It dates

to the Ramesside period.
\end{abstract}

\section{KEYWORDS}

Stela; Ramesside Period; A female Singer; لوحة؛ عصر الرعامسة؛ مغنية؛ هليوبوليي؛ Heliopolis; Tjauty- nedjem.

$$
\text { تشاوتى -نجم. }
$$

\section{INTRODUCTION}

The stela was discovered by an Egyptian mission led by Mr. Wahid Al. Arkan from the ministry of Tourism and Antiquities in the area of Ain Shames, which used to be a part of the vast cemetery of Heliopolis. This stela and another one had been reused during the Late Period in the platform of a mud brick tomb, located near the tomb of Panhsi. 


\section{DESCRIPTION:}

This stela is made of limestone with measures $52 \mathrm{~cm}$ in height, $38 \mathrm{~cm}$ width and $8 \mathrm{~cm}$ thickness. It is an example of funerary stelae, with a semicircular top connected to the body of the stela without any dividing line. It is a prominent stylistic feature of the stelae of the New Kingdom ${ }^{1}$. This differs from the design of the stelae of Middle Kingdom $^{2}$ and the Second Intermediate Period ${ }^{3}$, the upper edge being separated from the body of the stela by a dividing line. From the ancient Egyptian perspective, this rounded edge may have resembled the sun's inclined path through the sky ${ }^{4}$.

\section{THE UPPER REGISTER:}

Incised in sunken relief on the far left of the upper register, the god Osiris is standing on the Maat base. He is in a mummy form with a long strap in the back, also wearing the Atef-crown, a wide collar, and a false beard. In his right hand, he holds the $h k 3$ scepter and the $n h 3 h 3$ flagellum in his left hand. In front of him, there are four smaller figures of the sons of Horus ${ }^{\mathrm{a}}$ in a mummy form with animal heads except for Imsty. $\mathrm{He}$ is the first figure who has a human head while standing on the lotus flower and looking towards the owner of the stela. In front of Osiris there is a hieroglyphic

column incised in sunken relief. It reads as It It reads as follows: $\rightarrow$ sic $W$ sir Wnn- nfr ${ }^{\mathrm{b}} n b t 3 d s r^{\mathrm{c}}$ (Osiris Onnuphris the lord of the necropolis)

Incised in sunken relief are two women and a man who are depicted standing in front of Osiris. There is a stand between them and Osiris, above which is a nmst jar ${ }^{\mathrm{d}}$ covered with a lid, shaped as a falcon head. This jar is surrounded by small horizontal lines $^{\mathrm{e}}$. The stand also has on both sides two lettuces ${ }^{5}$. The first woman, who is the owner of the stela, is standing, depicted with incomplete facial features. She wears a tight long and transparent garment $\mathrm{f}$, covered with a loose gown with a sleeve veiling her left shoulder and reaching her elbow. In addition, this woman wears a short wig topped with a perfume cone $\mathrm{g}^{\mathrm{g}}$ and a lotus flower. She holds in her left hand a crooked

\footnotetext{
${ }^{1}$ Bosticco, Museo Archeologico di Firenze, Le Stele Egiziane del Nuovo Regno, Roma, 1965, Tafel .1, 4-8; El - Banna, JEA 76, (1990), p. 175, pl. XVI; Müller - Wollermann, "Der Mythos Vom Ritus (Erschlagen der Feinde)", GM 105, (1988), 69; Hermann, Die Stelen der Thebanischen Felsgräber der 18 Dynastie, 36, Abb. 4.

${ }^{2}$ CGC. 20240, CGC. 20445, CGC. 20537, CGC. 20556; Lange, (H.O.) ed., Grab- und Denksteine des Mittleren Reichs im Museum von Kairo, Vol. IV, Berlin, 1902; Tomich, GM 234 , (2012), figs. 4,7, 9; Abdalaal, "Three Unpublished Stelae from the Egyptian Museum, Cairo", in: Zahi A. Hawass (ed.), The Realm of The Pharaohs, Essays in Honor of Tohfa Handoussa, Cahier No. 37, Vol. 1, Le Caire, (2008), 46.

${ }^{3}$ Marée, Egyptian Stelae in The British Museum from The $13^{\text {th }}$ to $17^{\text {th }}$ Dynasties, Vol. 1, pls. 5-47.

${ }^{4}$ Westendorf, Ältägyptische Darstellungen des Sonnenlaufes auf der abschüssigen Himmelsbahn, 22, 75f; Hölzl, Die Giebelfelddekoration von Stelen des Mittleren Reichs, in: Beiträge zur Ägyptologie, Vol. 10, 10; Atallah, "Eine Stele aus dem Mittleren Reich im Ägyptischen Museum Kairo" in : Supplément aux Annales du Service des Antiquités de L'Égypte, Cahier No. 34, Vol. 1, 151.

${ }^{5}$ Farouk, ASAE 80, (2006), 199, taf. pl. 1.
} 
sistrum to indicate her priestly function, and raises her right hand in adoring attitude. Above her head two hieroglyphic columns are incised in sunken relief. They read as follows: $\leftarrow$

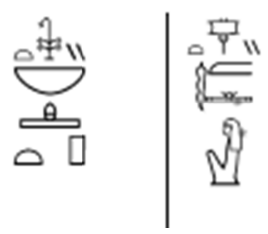

$\check{s} m^{c} y t^{\mathrm{h}} n b(t) h t p t^{\mathrm{i}} \underline{t} 3 w t y-n d m^{\mathrm{j}}$ (chantress of Nebet-Hetepet Tjauty- nedjem)

The stela shows another woman standing behind the first, also with incomplete facial features. She wears a similar garment, a long wig of which only one side depicted which is crowned with a perfume cone and a lotus flower. She is raising her hands in a worshiping posture. Above her head, hieroglyphic column is incised in sunken relief. It reads: $\leftarrow$

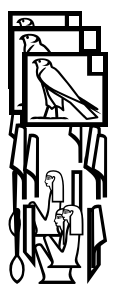

$H w t-H r y m 3^{e}(t)-h r w$ (Hathory justified)

At the right end of the upper register, a shaved-headed man with incomplete facial features is standing. He wears a long kilt extending from the waist to the middle of his leg and he raises his hands in a worshipping attitude. Two hieroglyphic columns are inscribed in sunken relief in front of his head. They read as follows: $\leftarrow$

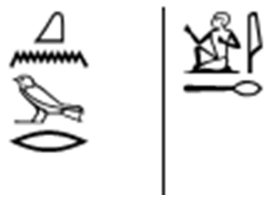

kn -wr $m 3^{\top}-h r w \quad$ (Qen-Wer justified)

\section{THE LOWER REGISTER}

The sacred bull $M r-W r^{k}$ is depicted in sunken relief at the far left of this register standing on a rectangular pedestal that lies on a sledge. There is an object in front of him that may be a lotus flower. The bull appears huge, with exaggerated penis and testicles. Between its horns is the sun disk, and there is a fan ${ }^{1}$ upon its back. Similar scenes of this sacred bull are depicted on stelae dating to the Ramesside Period ${ }^{1}$ such

1 Zayid, Trois Études d' Égyptologie, 33, fig.16. 
as the stela of $\mathrm{Hr}$-Min currently in the Louvre Museum (C 292) from Heliopolis ${ }^{1}$ and the stela of $p 3-s r$ recently kept in the magazine of El-Matariya (No. 3644) ${ }^{2}$. Above the head of the bull, three columns of sunken hieroglyphs: read as follows: $\rightarrow$

近

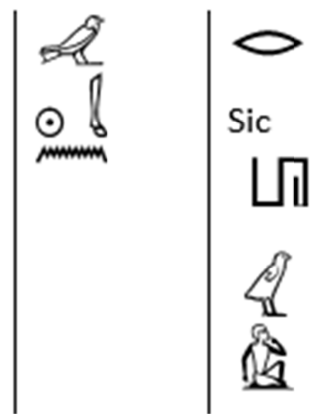

$M r-w r W h m n R^{\mathrm{m}}$ (Mer-Wer the herald of Ra)

Before the head of the bull, there are two hieroglyphic symbols

In front of the bull stands the owner of the stela $t 3 w t y$ - $n \underline{d} m$, who appears in the same posture as in the upper register, with the same unfinished facial features. Two columns of hieroglyphs above her head written in sunken relief read as follows: $\leftarrow$

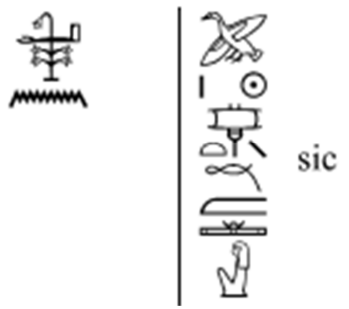

$\check{s} m^{c} y(t) n(t) P 3-R^{e \mathrm{n}} \underline{\underline{t}} 3 w t y-n \underline{d} m$ (the chantress of Pa-Ra Tjauty-nedjem)

Behind this woman, another female is raising her hands in an adoration, also with unfinished facial features and feet. She is wearing the same garment as the first woman and a tripartite wig topped by a perfume cone and lotus flower. Only the side and back parts of the wig are visible. This type of wig was widely worn during the New Kingdom ${ }^{3}$. Above the woman's head, two columns of hieroglyphs: read as follows: $\leftarrow$

\footnotetext{
${ }^{1}$ Desroches-Noblecourt, Un Siécle de Fouilles Francaises en Égypte, 268f, fig. 284; KRI. VII, 125(15).

${ }^{2}$ Ali, "Three Stelae from Ain-Shams", in The Horizon Studies in Egyptology in Honour of M. A. Nur El- Din, Vol. III, 65, pl. 1, Fig.1.

${ }^{3}$ Robins, JARCE 36, (1999), 63ff.
} 


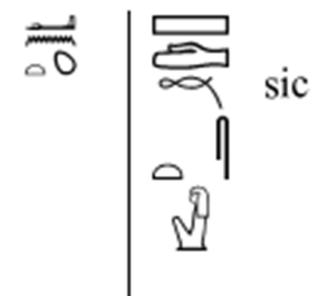

${ }^{e} n t \check{s} d t . s^{5}$ ( Anat Shedet $-\mathrm{s}$ )

A small girl with incomplete facial features and a naked body, except for a band around the waist, is seen at the far right of this register, probably a maid. She holds lotus flowers in her right hand while raising her left one in adoration. Incised above her head is a column of hieroglyphs.

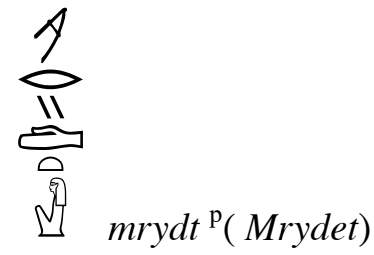

\section{COMMENTS}

a- The funerary tasks of the four sons of Horus in protecting the deceased is referred to in (Pyr. 552, 1333, 1334, 1983, 1984, 2078, 2079) ${ }^{1}$, (CT.VI, 110, $115)^{2}$ and (BD 17 and $\left.137 \mathrm{~A}\right)^{3}$.

The occurrence of the four sons of Horus on the walls of tombs and on funerary stelae while standing on a blue lotus flower, whose roots grow either from the base of Osiris' throne or from the feet of Osiris, began in the second half of the Eighteenth Dynasty. This is clearly represented on the walls of the tomb of Maya in Memphis and that of Neferhotep (TT 49) in Thebes ${ }^{4}$.This scene continued in the following periods, especially in the Ramesside Period as seen on the walls of TT 277 in Thebes ${ }^{5}$, on stela of Nb-Imn in the Cairo Egyptian Museum TR 5/7/24/10 (SR 11859) ${ }^{6}$, and the stela which was found near the tomb of Hori at Tell Basta ${ }^{7}$. The scene of the four sons sons of Horus was widely represented on funerary stelae, on which the deceased worships Osiris; it is likely that these all date to the Ramesside Period ${ }^{8}$.

\footnotetext{
${ }^{1}$ Faulkner, The Ancient Egyptian Pyramid Texts, 109, 210, 286, $296 \mathrm{f}$.

${ }^{2}$ Faulkner, The Ancient Egyptian Coffin Texts, 149f; Servajean, (Frédéric), “ Le Louts emergeant et les Quatre Fils d' Horus, 268.

${ }^{3}$ Faulkner,The Ancient Egyptian Book of the Dead,47, 128.

${ }^{4}$ Martin, The Hidden Tombs of Memphis, 171, fig. 109; Davies, The Tomb of Nefer-Hotep at Thebes, pl. XXX; Koemoth, “ Les Quatre Fils d' Horus sur le Pavois ou sur Le Lotus de L' Image au Rituel”, OLA 191, Leuven, (2009), 381.

${ }^{5}$ Vandier d' Abbadie, "Deux Tombes Ramessides à Gournet - Mourrai", pl. XXI; Hornung, The Valley of the Kings, Horizon of Eternity, fig. 87.

6 Radwan, Darstellungen der Aufgehenden Sonne auf Einigen Stelen der Ramessidenzeit", in : Westendorf, W., Studien zu Sprache und Religion Ägyptens,824, taf. 3 (3a).

${ }^{7}$ Habachi, Tell Basta, 101, pl. XXXVIIIA.

${ }^{8}$ Hodjash, The Egyptian Reliefs and Stelae in the Pushkin Museum of Fine Arts, Moscow, Leningard, 1982, 141f, fig. 83; Radwan, ASAE 71, (1987), 224, pl. III; Moursi, GM 105, (1988), 59 - 61, pls. I, II.
} 
By closely examining scenes of the four sons of Horus on the lotus flower in front of Osiris, it appears that their heads do not display a consistent direction, sometimes facing the deceased who is worshiping Osiris, like the scene depicted on the walls of the tomb of Amunmes (TT 373) in Thebes ${ }^{1}$ and stela of Pth-m-wi3 in the British Museum (No.167) from the Nineteenth Dynasty ${ }^{2}$, as well as the stela presented presented in this study. In other examples, they look towards Osiris, in tomb of Neferhotep (TT 257) in Thebes ${ }^{3}$ from the Ramesside Period. This motif is frequently shown on stelae dating to the Ramesside Period.

It is possible that the deceased selected to have the four sons of Horus on the lotus flower in front of Osiris depicted to express the desire to be resurrected, given that ancient Egyptians believed that the blue lotus flower was a symbol of the resurrection. In accordance with Hermopolitan cosmogony, the child god Ra, who created all the gods and creatures, emerged from the lotus flower ${ }^{4}$. This is also affirmed in the Papyrus of Ani of the Nineteenth Dynasty where Ani's head is depicted emerging from the lotus flower as a symbol of resurrection ${ }^{5}$.

b- The title wnn $n f r$, associated with Osiris, dates to the Middle Kingdom ${ }^{6}$, as seen in the $h t p-\underline{d} i-n s w$ formula on a stela in the Cairo Egyptian Museum (CGC 20578) ${ }^{7}$. This title continues to be seen archaeological sources from the New Kingdom onwards. It is mentioned in the second hour of the Amduat Book ${ }^{8}$, and on the walls of the temple of Seti I in Abydos ${ }^{9}$. It also appears on many funerary stelae dating to the New Kingdom, such as the stela in the Cairo Egyptian Museum TR 10/6/24/8 (SR. 11732) from the Eighteenth Dynasty ${ }^{10}$ and the Ramesside stela 1330 stored in Giza main magazine ${ }^{11}$. Many funerary stelae dating to the Late Period, such as that of Horwadja in the Cairo Egyptian Museum J E $41332^{12}$, show such title.

c- The epithet $n b t 3 \underline{d} s r$, was associated with a number of deities of the West, the necropolis, and the death like Webwawet ${ }^{13}$, Osiris ${ }^{14}$, and Ptah-Soker-Osiris ${ }^{15}$.

d- The contents $n m s t$ jar varied between cold water, milk, beer, or perfumes ${ }^{1}$. It was also used as a purification jar during funerary rituals, as cited in Spell

\footnotetext{
1 Seyfried, Das Grab des Amonmose (TT 373),122, fig. 151; Hassan, La Tombe du Prince Khaemouaset ( V dR no. 44 ), 78f, pl. LXXV.

2 James, The British Museum, Vol. 9, 29, pl. XXV.

${ }^{3}$ Mostafa, Das Grab des Neferhotep und des Meh ( TT 257), 23, fig. 4.

4 Bonnet,Reallexikon der Ägyptischen Religionsgeschichte, 509; Pischikova, (E. V.), JARCE 31, (1994), p. 70; Hart, The Routledge Dictionary of Egyptian Gods and Goddesses, 134.

${ }^{5}$ Spell 81 A; Faulkner, The Ancient Egyptian Book of the Dead, 79. For more information about the four sons of Horus See: Abd El Sattar, SHEDET. 5, (2018), 24-29; Hornung, The Egyptian Book of Gates, 372 f, 377-379; Dodson " Four Sons of Horus ', OEAE 1 562; Teeter, Religion and Ritual in Ancient Egypt, 139; Koefoed - Petersen, Catalogue des Sarcophages et Cercueils Égyptiens, pl. XXXI(6); Manniche, Lost Ramessid and Post - Ramessid Private Tombs in the Theban Necropolis, 22f, figs. 8, 9; Feucht, Das Grab des Nefersecheru (TT296), pl. X (6); Scalf, F., Book of The Dead, Becoming God in Ancient Egypt, 164, fig. 14.4.

${ }^{6} L G G$ II, 541. $L G G$ II, 541.

${ }^{7}$ Lange, Grab- und Denksteine des Mittleren Reichs im Museum von Kairo, Vol. II, 218.

${ }^{8}$ Hornung, The Egyptian Amduat, The Book of Hidden Chamber; 63.

${ }^{9}$ Calverley, The Temple of King Sethos1 at Abydos, Vol. 1, pl. 3.

${ }^{10}$ Assem, MDAIK 62, (2006), 63, 65f, pl. 15.

${ }^{11}$ El-Saady, Z̈̈S 122, (1995), 101, 103, fig. 2.

12 Selim, $S A K$ 28, (2000), 244, taf. 12.

${ }^{13} \mathrm{KRI}$ 1, 332 (13 ); Abdalaal, MDAIK $62,(2006)$, 4.

${ }^{14}$ Habachi, Tell Basta, 101 f, pl. XXXVIII A.

${ }^{15}$ Davies, Seven Private Tombs at Kurnah, 6. pl. III.
} 
1180 of the Pyramid texts ${ }^{2}$. A similar falcon-headed $n m s t$ jar shown on this stela is represented on the walls of the temple of Ramesses II in Abydos ${ }^{3}$.

e- Small horizontal lines are depicted around the jar, perhaps referring to the sweet scents from the essential oils contained in the jar spreading, as these oils are invisible. These lines may also imply the shining metal of the jar, such as gold, as is the case on the stela in the current study. This was repeated on many stelae ${ }^{4}$, as depicted on the stela of Houy from the Ramesside period ${ }^{5}$.

f- The fashion of the garment of the women was popular in the Ramesside period as shown on the walls of tombs and on stelae dating to this era ${ }^{6}$. Among others, the stela of Thoth, in the Leiden National Museum (V 51), and the stela 593 in Zagreb museum of Egyptian archaeology, Yugoslavia ${ }^{7}$.

g- The unguent cone appeared, as an artistic element, above men's and women's wigs in the Eighteenth Dynasty. Subsequently it was widely worn by women, occasionally with a lotus flower attached to it, during the Nineteenth Dynasty ${ }^{8}$, as shown on the stela of Houy in the Egyptian Museum in Cairo (JE 36853) ${ }^{9}$, the Ramesside stela of Twnn-nhb-Hnsw in the British Museum (No. 700) ${ }^{10}$. This cone was used to moisten the hair ${ }^{11}$.

h- The title $\check{s} m^{c} y t$ means a female singer ${ }^{12}$. It appears with this form $\check{s}^{c}{ }^{c} w$ only once in the Old Kingdom tomb of Deja in Deir El Gebrawi in Assyut ${ }^{13}$.

This title becomes more common from the Middle Kingdom, since there are several

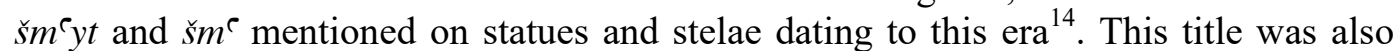
used in its feminine form $\check{s} m^{c} y t$ from the New Kingdom onwards ${ }^{15}$, as seen on the aforementioned stela of Thoth dating to the early Nineteenth Dynasty ${ }^{16}$

i- Regarding to the title's association with the goddess Nebet-Hetepet as referred to in the texts of this stela, it is worth noting that Suzanne Onstine, in her study of the role of the chantress 'šm $y t^{\top}$ ' in ancient Egypt, recorded 929 cases of the

${ }^{1}$ Kees, (H.), Der Götterglaube im Alten Ägypten, 264f; Tawfik, MDAIK 35, (1979), 343.

${ }^{2}$ Pyr.1180; Faulkner, The Ancient Egyptian Pyramid Texts, 190.

${ }^{3}$ Iskander, The Temple of Ramesses II in Abydos, Vol. 1, 350, pl. 4.5.11.

${ }_{5}^{4}$ Demarée, The $3 h i$ ỉ $n$ R R-stelae: on Ancestor worship in Ancient Egypt , pl. II (ca $\left.1 / 4\right)$.

${ }^{5}$ Valbelle, $B I F A O 75,1975,139$, pl. XIX.

${ }^{6}$ Staehelin, "Tracht", LÄ VI, Col. 730; Leblanc, Ta Set Neferou une Necropole de Thebes - Ouest et Son Histoire 1, pl. CLXIV a; Green, " Clothing and Personal Adornment", OEAE II, 277; Bierbrier, (M. L.), The British Museum, Vol. 12, 19, pl. 61, (349 ).

${ }^{7}$ Saleh, Les Antiquités Égyptiennes de Zagreb, 35, fig. 17.

${ }^{8}$ Demarée, The $3 h$ ỉ $k r n$ Rc-stelae, pls. IV , V , VII , X, XI , XII; Lacau, Stèles du Nouvel_Empire, in Catalogue général des antiquités égyptiennes du Musée du Caire, Nos 34001-34189, pls. XLVII (34097 ),-LV (34133) (usually CG 34097); Mostafa, Das Grab des Neferhotep und des Meh, 30, Fig. 8; Tosi, Stele Ealtre Epigrafi di Deir El Medina, Vol. 1, 105 (No. 50069 ); Green, “ Hairstyles”, OEAE II 73.

${ }^{9}$ Radwan, “ Six Ramesside Stelae in the Popular Pyramidion - Form”, 225, pl. IV.

${ }^{10}$ Bierbrier, The British Museum, Vol. 12, pl. 71, no.700.

${ }^{11}$ Cherpion, BIFAO 94, (1994), 79, 81; Muhammed., ASAE LIX, (1966), 175.

${ }^{12}$ Faulkner, $A$ Concise Dictionary of Middle Egyptian, 266; $W b$. IV, 479 (8).

${ }_{14}^{13}$ Davies, The Rock Tombs of Deir El Gebrawi, Vol. II, 8, pl. VII.

${ }^{14}$ Moussa, MDAIK 31, (1975), 93, 94, Abb. 1; Ward, Index of Egyptian Administrative and Religious Titles of the Middle Kingdom, 175 (nos. 1515, 1516); Wb. IV, p. 479(8); Stefanović, GM 220, (2009), 96; Lange, Grab- und Denksteine des Mittleren Reichs im Museum von Kairo. Vol. I, 167f ( CG no 20142).

${ }^{15}$ Naguib, Le Clergé Féminin d'Amon Thébain á La 21 Dynastie, 236; Onstine, The Role of the Chantress (šm $\left.{ }^{`} y t\right)$ in Ancient Egypt, 71, 80, 82f.

${ }^{16}$ Affara, "A New Kingdom Stela in the National Museum of Antiquities, Leiden”, 151, fig.1. 


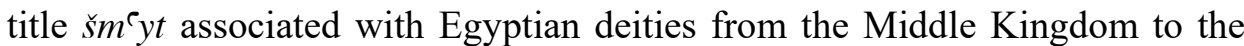
Ptolemaic Period ${ }^{1}$. However; Nebet-Hetepet is not listed among these.

The goddess Nebet-Hetepet -whose name has been translated "the lady of the offerings", "the lady of Hetepet city", "the lady of satisfaction"4, and "the lady of sacrifice" - was worshiped in the thirteenth nome of Lower Egypt $h k 3-{ }^{-} n d j$ in a suburb called Hetepet that was situated to the north of Heliopolis ${ }^{6}$. Senusret I built there a temple for this goddess ${ }^{7}$. Nebet-Hetepet was also associated with many ancient Egyptian deities, among which the most distinguished one was Hathor. They merged into one goddess known as Hathor- Nebet-Hetepet ${ }^{8}$.

j- With regard to the personal names mentioned in the upper register, Ranke

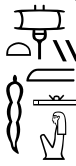

reads the name

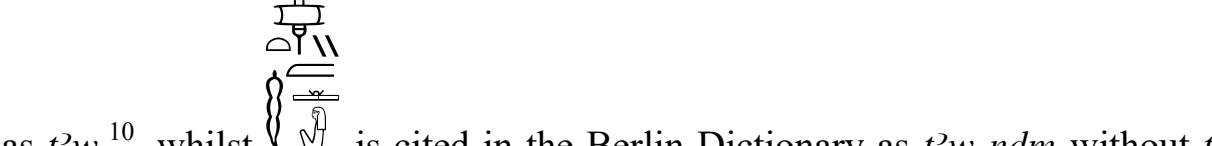
as $t 3 w^{10}$, whilst 1 is cited in the Berlin Dictionary as $\underline{t} w w n d m$ without $t y$, which means 'the gentle wind"11. As for the names Hwt - Hry and $k n-w r$ are not attested in Ranke ${ }^{12}$ but a nearly similar name to that of Hathor is found on the stela 45 of $\mathrm{Rm}^{-}$, preserved in Giza main magazine : a lady is called Hathor $^{13}$.

k- The name of the sacred bull $M r-W r$ occurred for the first time in the Coffin Texts as $N m-W r{ }^{14}$. While the Bull of Iunu is referred to in the Pyramid texts, its name is not explicitly stated ${ }^{15}$. But this reference from the Pyramid texts most likely indicates the $M r-W r$ bull considering that Heliopolis was its cult center of worship ${ }^{16}$. Two burials of this bull were found in Heliopolis in Arab Al Tawil, dating to the reigns of Ramesses II and VII ${ }^{17}$. Moreover, the papyrus

${ }^{1}$ Onstine, The Role of the Chantress (šm $\left.{ }^{C} y t\right)$ in Ancient Egypt, 203-242.

${ }^{2}$ CT VI, 274b; Faulkner, The Ancient Egyptian Coffin Texts, 226.

${ }^{3}$ Pyr. 814a; Mercer, The Pyramid Texts, 152.

${ }^{4}$ Wilkinson, The Complete Gods and Goddesses of Ancient Egypt, 156.

${ }^{5} L G G$ IV, 111.

${ }^{6}$ Guglielmi, (W.), "Nebet - hetepet”, LÄ IV, Cols. 362, 363; Gauthier, Dictionnaire des Noms Géographiques Contenus dans Les Textes Hiéroglyphiques, 145.

${ }^{7}$ Vandier, RdE 16, (1964), 70f, 78.

${ }^{8}$ Saleh, Excavations at Heliopolis, Vol. 1, 11; LGG IV, 111; Faird, MDAIK 35, (1979), 72(3); Refai, GM 181, (2001), 90; Vandier, RdE 16, 55-146; 17 (1965), 89-176; 18(1966), 67-142; 20 (1968), 135148.

${ }^{9}$ Ranke, 193 (25). PN I, 193.

${ }^{10}$ Ranke, $P N$ I, 388

${ }^{11} \mathrm{~Wb}$. IV, p. 352(18).

${ }^{12}$ Ranke $P N \mathrm{I}, ? ? ? ?$

${ }^{13}$ Abdel-Aal, GM 171, (1990), 8, fig. 1.

${ }^{14}$ Wilkinson, The Complete Gods and Goddesses of Ancient Egypt, 174; LGG III, p. 328; CT V, 191b, 205, CT VI, 414; de Buck, The Egyptian Coffin Texts, Vol. V, Spell 404; Faulkner, The Ancient Egyptian Coffin Texts, Vol. II,.38, 55, 307.

${ }_{15}$ Pyr.71b; Faulkner, the Ancient Egyptian Pyramid Texts, $133 \mathrm{f}$.

${ }^{16}$ Redford, The Ancient Gods Speak: 31.

${ }^{17}$ Daressy, ASAE XVIII, (1919), 196; id., ASAE XVIII, p. 211; PM. IV, p. 59; Raue, Heliopolis und das Haus des Re, 106-108.

- 63 - A RAMESSIDE STELA OF THE CHANTRESS 
No. 10689 in the British Museum, which dates to the reign of Ramesses II, contains a text about the assistance of $M r-W r$ who resides in Heliopolis in the purification of the deceased ${ }^{1}$.

Manetho has claimed that this bull had been worshiped before the Middle Kingdom ${ }^{2}$. The worship of the $M r-W r$ bull spread widely from the reign of Thutmose III ${ }^{3}$. The $M r-W r$ bull held many titles similar to those of Osiris. He also assumed the title $W$ sir $M r-W r$ as a dead bull after death. This title is inscribed on the Heart Scarab of the mummy of the $M r-W r$ bull found in Heliopolis, preserved in The Toledo Museum of Art in $\mathrm{USA}^{4}$. Furthermore, this title attached to the $M r-W r$ bull is inscribed on statues and canopic jars dating to the Ramesside Period ${ }^{5}$. It was also given the title Wnn $n f r$ from the New Kingdom ${ }^{6}$, which is already one of Osiris's titles ${ }^{7}$. It is mentioned on stelae, such as the Egyptian Museum (TR 2/2/21/1) from the reign of Ramesses $\mathrm{II}^{8}$, and on the walls of the $M r-W r$ tomb in Arab Al Tawil in Heliopolis from the reign of Ramesses VII ${ }^{9}$.

1- The fan is used as an attribute for the bull-god, as depicted on the stela of $p 3-$ $s r$, which dates to Ramesside period ${ }^{10}$, the stela 1327 stored in Giza main magazine from the same period ${ }^{11}$, and the presently studied one.

m- The title whm $n R^{c}$ was held by the $M r-W r$ bull ${ }^{12}$ during the Eighteenth Dynasty, and it means the herald of $\mathrm{Ra}$ who acquainted his desires and decisions ${ }^{13}$. It is probable that the bull held such a title due to being one of the deities of Heliopolis, which was the center of the worship of Ra. This title continued to be associated with the $M r-W r$ bull until the Greco-Roman period $^{14}$.

Such association between the title whm $n R^{e}$ and the $M r-W r$ bull; appears on numerous sources, including statues dating to the Eighteenth Dynasty ${ }^{15}$. It was also common on many stelae of the Ramesside Period ${ }^{16}$. For instance; a stela dating to the $26^{\text {th }}$ year of the reign of Ramesses II in the Cairo Egyptian Museum (TR 2/2/21/1) ${ }^{17}$, the stela of $\mathrm{Hr}$-Min (Louvre Museum C 292) ${ }^{18}$, and

\footnotetext{
${ }^{1}$ Gardiner, Hieratic Papyri in the British Museum, Vol. 1, 78, 112, Pl. 60.

${ }^{2}$ KaKosy, “Mnevis”, LÄ IV, Col. 165.

${ }^{3}$ Dodson, "Bull Cults", in: Salima Ikram (ed.), Divine Creatures, Animal Mummies in Ancient Egypt, 92.

${ }^{4}$ Spiegelberg, JEA 14, no. 1/2, (1928), 12, fig. 2.

${ }^{5}$ Dodson," The Canopic Equipment from the Serapeum of Memphis”, in: Anthony Leahy \& John Tait, Tait, Studies on Ancient Egypt in Honour of H. S. Smith, 65; Touraeff, JEA 4, no. 2/3, (1917), 120, pls . XXIII, XXV.

${ }^{6} L G G$ III, 329.

${ }^{7}$ Lurker, The Gods and Symbols of Ancient Egypt, 93.

${ }^{8}$ KRI II, 363(15).

${ }^{9}$ Daressy, “La Tombe du Mnévis de Ramsès VII”, 215.

${ }^{10}$ Ali, "Three Stelae from Ain-Shams", 65f, pl.1, fig.1.

${ }^{11}$ El-Saady, "Two Heliopolitan Stelae of the New Kingdom”, 101, 103, fig. 1.

12 And other Egyptian deities: $L G G$ II, 523.

${ }^{13}$ Wb.1, 344(15); Bell, Cults and Creeds in Graeco- Roman Egypt, 10; Sabbahy, " The Mnevis Bull at Horizon of the Disc", in Amarna Letters 4, 37.

${ }^{14} L G G$ II , 523 .

${ }^{15}$ Urk. IV, 1372(15).

16 Desroches- Noblecourt, ed., Un Siécle de Fouilles Francaises en Égypte, pp. 268f, fig. 284; Petersen, O. K., Les Stéles Égyptiennes, 34, taf. 41; Moursi, SAK. 14, ( 1987), 225f, 228, 233, 235, 237, Abbs. 1, 2, 4, 5 .

${ }^{17}$ KRI II, 363(12).

${ }^{18}$ KRI VII, 125(15).
} 
the stela of Trh-ms (Berlin Museum No. 14200), which was found in Heliopolis ${ }^{1}$.

n- The title of $\check{s} m^{\ulcorner} y t$, which is associated with the deity $P 3-R^{c^{2}}$, appears on many many stelae dating to the Nineteenth Dynasty, among these that of $R^{\mathrm{c}}-\mathrm{ms}$ (British Museum No. 139) ${ }^{3}$ and the stela of Maya (Egyptian Museum in Cairo TR $14 / 10 / 69 / 1)^{4}$. It is also depicted on stelae dating to the Twentieth Dynasty such as the stela of Amun-em-wia (British Museum No. 1183) ${ }^{5}$. It is to be noted that the owner of this stela holds two titles, namely $\check{s}^{\ulcorner} y(t) n(t) p^{3} R^{c}$ and $s^{\top}{ }^{\top} y t n b(t) h t p t$.

o- - Ranke and Schneider have not mentioned the name ' $n t$ šdt.s despite citing other names which have, as a part of their structure, the name of the Syrian goddess ' $n t$, appeared in Egypt at the beginning of the New Kingdom and her worship widespread by the Ramesside period, as one of the foreign deities ${ }^{6}$.

p- The unique name $m r d t$ is not attested in Ranke ${ }^{7}$; suggesting that it was perhaps foreign.

\section{PALEOGRAPHIC COMMENTS}

- Osiris's name is written with the determinative 15 on this stela. Yet, this determinative generally appeared in the New Kingdom, as seen on a stela preserved in the Cairo Egyptian Museum (JE 33238) and dating to the time of Thutmose IV or Amenhotep III ${ }^{8}$, and another stela from the reign of Ramesses II (Cairo Egyptian Museum CGC 34517).

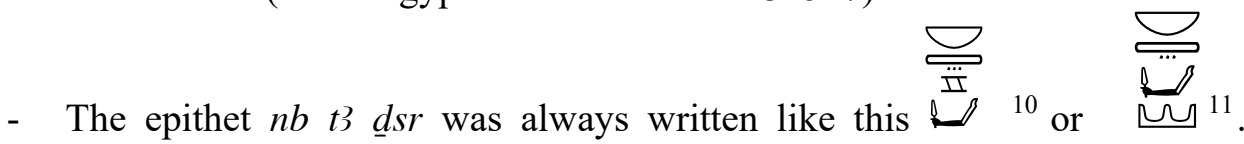
Hence, the artist of the stela under consideration wrote this title incorrectly as , as, unusually the sign $\underline{d} s r$ came before the sign $t 3$.

- The maat sign in the upper register is written with the reed sign instead of the feather in the word $m 3^{-}-h r w$.

- $\quad$ Regarding to the writing of the name of the $M r-W r$ bull, it was written in different ways including 口命 政 $\Rightarrow$.

\footnotetext{
${ }^{1}$ Moursi,“Corpus der Mnevis - Stelen und Untersuchungen zum Kult der Mnevis - Stiere in Heliopolis Heliopolis 1", 225f, Abb. 1.

${ }^{2} \mathrm{~Wb}$. II, 401(8).

${ }^{3}$ KRI IV, 124f; James, The British Museum, Vol. 9, 24 f, pl. XX.

${ }^{4}$ KRI III, 280f; Gaballa, BIFAO 71, (1972), 132.

${ }^{5}$ Bierbrier, The British Museum, Vol. 10, 42, pl. 99.

${ }^{6}$ Ranke, PN I, 69,70; Schneider, Asiatische Personennamen in Ägyptischen Quellen des Neuen Reiches, . 72f.

${ }^{7}$ Ranke, (H.), PN I, ??

${ }^{8}$ Abdalaal, "Three Unpublished Stelae from the Egyptian Museum, Cairo", 50-53, fig. 3; Wb.1, 359(5). 359(5).

${ }^{9}$ Lowle, "Two Monuments of Perynefer, a Senior Official in the Court of Ramesses II", 57, fig. 1.

${ }^{10}$ Atallah, Eine Stele aus dem Mittleren Reich im Ägyptischen Museum Kairo”, 151f; Bakry, $A S A E$ LVII, (1962), 12, pl. II.

${ }^{11} \mathrm{~Wb}$. II , 227(10).

${ }^{12} L G G$ III, 328.
}

- 65 - A RAMESSIDE STELA OF THE CHANTRESS 
or $\bigsqcup$ may serve as a determinative of the word $M r$ in the structure $M r$ $W r=\frac{1}{5}$, or that this may be read as the phonogram $M r$ in the same structure $\square \prod{ }^{1}$. According to what is mentioned above, and by

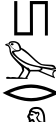

comparing the writing's form of the name $M r-W r$ If on the stelae of the Ramesside Period (e.g. Cairo Egyptian Museum TR 2/2/21/1) ${ }^{2}$, it is obvious that the writer who inscribed the texts of the examined stela wrote the sign $\bigsqcup$ incorrectly uniquely since it should have been written as $\bigsqcup$

- Concerning the letters

- Concerning the letters they may belong to the word whm, according to Leitz ${ }^{3}$, Hannig ${ }^{4}$ and Lesko ${ }^{5}$. The artist had written them wrong in the line line before because there is not enough space, which is occupied by the sun disk on the head of the bull.

- The artist who inscribed the texts of the stela replaced the sign $n d m$ with $\infty m h$ in the name of $t 3 w t y-n d m$ in the lower register, even though he already wrote the name correctly in the upper register. And the word $n d m$ is mentioned in the Berlin Dictionary with the sign $\$$ not $\infty$.

- The artist replaced the sign with $\infty$ in the name of ' $n t \check{s} d t . s$ where he used the sign $\propto$ as a phonetic complement to $\check{s} d t$ instead of the right sign $\breve{s}$ as mentioned in $\mathrm{Wb}^{7}$.

\section{CONCLUSIONS}

According to this presentation, it appears that the owner of the stela wanted to display a selection of deities who were related to one another, and some associated with Heliopolis where the stela was found. It is evident from her title $\varsigma^{c} m^{c} y(t) n b(t)-h t p t$ that the owner was a chantress of the goddess Nebet-Hetepet who was worshiped in Heliopolis $^{8}$. Within the framework of the relationship among the gods Ra and Osiris, the owner of the stela chose to incarnate the superiority of Osiris which he reached during the New Kingdom, nearly equal to the rank of Ra. This is manifested in the incorporation of Osiris and $\mathrm{Ra}$ into a ram-headed mummy that symbolically represented the nocturnal sun. This is evident from the scenes of the tomb of Nefertari, wife of Ramesses $\mathrm{II}^{9}$. Moreover, Osiris is identical to Ra at the third hour of

\footnotetext{
${ }^{1}$ Gardiner, Egyptian Grammar, 93, Sign- List O (5).

${ }^{2}$ El - Alfi, JEA 58, (1972), 177, fig.2.

${ }^{3} L G G$ II, p. 523.

${ }^{4}$ Hannig, Die Sprache der Pharaonen. Großes Handwörterbuch Ägyptisch-Deutsch, 226.

${ }^{5}$ Lesko, A Dictionary of Late Egyptian, vol. 1, 109.

${ }^{6} \mathrm{~Wb}$. II, p. 378(8-21).

${ }^{7} \mathrm{~Wb}$. IV, pp. 560-563.

${ }^{8}$ Guglielmi," Nebet - hetepet”, Cols. 362, 363.

${ }^{9}$ Wilkinson, The Complete Gods and Goddesses of Ancient Egypt, 120, 122; Assem, "Stela of Ameneminet (TN. 10/6/24/8)", 66.
} 
of the Book of the Gates ${ }^{1}$, in which it is stated that Osiris rests in Ra and Ra rests in Osiris. It is also mentioned in chapter 182 of the Book of the Dead ${ }^{2}$ as well as the texts inscribed on one of the chapels of Tutankhamun ${ }^{3}$.

The artist of the stela expressed the identification of $\mathrm{Ra}$ to Osiris on this stela is expressed through the depiction of Osiris as the god of the underworld and the popular god amongst most of the population during the New Kingdom ${ }^{4}$, and through the representation of the symbols of Ra in the form of the $M r-W r$ bull which was considered Ra's herald ${ }^{5}$. The $M r-W r$ bull was associated with $\mathrm{Ra}$ by means of the fore mentioned title and the representation of the sun disk between its horns as being one of the deities of Heliopolis which was the main cult center of $\mathrm{Ra}^{6}$. Just as the $\mathrm{Mr}$ $W r$ bull was associated with $\mathrm{Ra}$, it was also connected to Osiris since it held the title "Osiris" when it died", as well as holding one of Osiris's titles, namely Wnn $n f r^{8}$. Within the same concept, the artist included the four sons of Horus as they are related to both Osiris and Ra. They guarded the mummy of Osiris in chapters 17 and $137 \mathrm{~A}$ of the Book of the Dead ${ }^{9}$. They also fought against the serpent Apep and its allies who who were the enemies of Ra according to the Books of the Gates and in the Amduat on the walls of the tomb RamessesVI ${ }^{10}$.

All the deities represented on the stela are linked with Heliopolis. Osiris is a member of the Ennead of Heliopolis; he is the son of Geb and Nut according to the Pyramid Texts $^{11}$. His relationship with Heliopolis is further reinforced by the discovery of a stela currently preserved in the magazine of El-Matariya dating to the Ramesside Period; it contains the phrase Wsir hrj - ib Iwnw (i.e. Osiris who resides in Heliopolis $)^{12}$. Concerning the god $M r-W r$, he was worshiped at Heliopolis where two Ramesside tombs were discovered ${ }^{13}$. As for the relationship of the four sons of Horus with Heliopolis, this may be attributed to their connection with the Osiris myth, which took place in the Delta marshes ${ }^{14}$.

Despite of the artist's ingenuity in depicting the deities of the stela under discussion he lacked expertise in his writing skills. This is manifest in the many errors detected in the text of the stela. Furthermore, the titles and personal names are briefly mentioned, without any reference to the relationship between the figures depicted on the stela. As a result, it is unknown; whether they descended from the same family. But as it was

${ }^{1} L G G \mathrm{~V}, 784$.

${ }^{2}$ Spell 182; Faulkner, The Ancient Egyptian Book of the Dead, p. 181; Hart, The Routledge Dictionary of Egyptian Gods and Goddesses, 134.

${ }^{3}$ Piankoff, The Shrines of Tut-Ankh-Amon, 65. pl. 21.

${ }_{5}^{4}$ Sadek, Popular Religion in Egypt during the New Kingdom, 108.

${ }^{5}$ Barguet, Le Livre des Morts des Anciens Egyptiens, 136; Bell, Cults and Creeds in Graeco- Roman Egypt, 10.

${ }^{6} \mathrm{El}$ - Alfi, "Recherches Sur Quelques Scarabées de Ramsès II", 177, fig. 2.

${ }^{7}$ Spiegelberg, "A Heart Scarab of the Mnevis Bull", 12, pl. IV (2).

${ }^{8}$ Lurker, The Gods and Symbols of Ancient Egypt, 93.

${ }^{9}$ Faulkner, The Ancient Egyptian Book of The Dead, 47, 128.

${ }^{10}$ Piankoff, The Tomb of Ramesses VI, vol. 1, 203f, 270, pls. 58, 59, 89, figs. 62, 63, 80.

${ }^{11}$ Griffiths, "Osiris", LÄ IV, Col. 625; Pyr. 1655; Faulkner, The Ancient Egyptian Pyramid Texts, 247; Kees, Der Götterglaube im alten Ägypten, 264.

${ }^{12}$ Alī, "Three Stelae from Ain-Shams", 68f, pl. III, fig. III.

${ }^{13}$ Daressy, (M.G.), "La Tombe d' un Mnévis de Ramsés II”, p. 196; id., "La Tombe d’ un Mnévis de Rams s VI", p. 211.

${ }^{14}$ Servajean, "Le Lotus émergeant et les Quatre Fils d' Horus. 264.

- 67 - A RAMESSIDE STELA OF THE CHANTRESS 
customary for ancient Egyptians to depict their family on their own stelae, it is possible that all the figures depicted on the stela are members of the family of $t 3 w t y$ $n \underline{d} m$.

\section{CHRONOLOGY}

This stela most likely dates to the New Kingdom, and specifically to the Ramesside period.

The following evidences;-supports this dating:

- The lack of dividing line between the upper curved edge and the body of the stela is considered as a feature of stelae of the New Kingdom.

- The worship of Osiris was a motif commonly represented on stelae of the Ramesside Period.

- The four sons of Horus were first depicted above a lotus flower placed in front of Osiris on stelae of the second half of the Eighteenth Dynasty, and this depiction became popular on stelae of the Nineteenth Dynasty.

- The garments of the women depicted on the stela of the study show the fashion of the Nineteenth Dynasty, especially the sleeves, which reach the elbows.

- The perfume cone with the lotus flower attached to it, above the women's wig is prevalent in scenes of the New Kingdom, and the Nineteenth Dynasty in particular.

- The $M r$ - $W r$ bull was first depicted in scenes of the Eighteenth Dynasty, and it was widely represented on stelae of the Ramesside Period.

- The writing of Osiris's name with the determinative shown on the stela under consideration was common in the New Kingdom.

- The title Whm $n R^{e}$ "Herald of Ra" was first associated to the $M r-W r$ bull in the Eighteenth Dynasty.

- The title $\check{s}^{c} y(t) n(t) P 3 R^{\ulcorner}$was commonly found on stelae of the Ramesside Period.

- The presence of the name of the foreign goddess ' $n t$ within the structure of personal names was common in the New Kingdom, and the Nineteenth Dynasty in particular. 


\section{BIBLIOGRAPHY}

1. Abdalaal, Aisha M., "Three Unpublished Stelae from the Egyptian Museum, Cairo", in: Zahi A. Hawass (ed.), The Realm of The Pharaohs, Essays in Honor of Tohfa Handoussa, Cahier No. 37, Vol. 1, Le Caire, (2008), 45-61.

2. "A Late Middle Kingdom Offering Table Cairo Temp. No. 25.10.17 .1”, MDAIK 62, (2006), 1-6.

3. Abdel-Aal, S., "A Family stela from Kafr el-Gabal”, GM. 171, (1990), 7-11.

4. Abd El Sattar, I, "The Anthropoid Wooden Coffin of Sn (=J) - JW in Cairo Museum( CG.61010.1-2)”, SHEDET. 5, (2018), 17-34.

5. Affara, M, "A New Kingdom Stela in the National Museum of Antiquities, Leiden", JARCE 46, (2010), 147-157.

6. Alfi, M, "Recherches Sur Quelques Scarabées de Ramsès II", JEA 58, (1972), 176-181.

7. Ali, N., "Three Stelae from Ain-Shams", in The Horizon Studies in Egyptology in Honour of M. A. Nur El-Din, Vol. III, Cairo, (2009), 65-75.

8. Assem, R., "Stela of Ameneminet (TN. 10/6/24/8) ", MDAIK. 62, (2006), pp. 63-66.

9. Atallah, M., "Eine Stele aus dem Mittleren Reich im Ägyptischen Museum Kairo" in: Supplément aux Annales du Service des Antiquités de L'Égypte, Cahier No. 34, Vol. 1, Le Caire, (2005), 151-158.

10. Bakry, H., "Two New- Kingdom Stelae", ASAE LVII, (1962), 9-14.

11. Barguet, P., Le Livre des Morts des Anciens Egyptiens, Paris, (1967).

12. Bell, H., Cults and Creeds in Graeco- Roman Egypt, Liverpool, (1954).

13. Bierbrier, M., The British Museum, Vol. 12, London, (1993).

14. ، The British Museum, Vol 10, London, (1982).

15. Bonnet, H., Reallexikon der Ägyptischen Religionsgeschichte, Berlin, (1952).

16. Bosticco, S., Museo Archeologico di Firenze, Le Stele Egiziane del Nuovo Regno, Roma, (1965).

17. Calverley, A., The Temple of King Sethos 1 at Abydos, Vol. 1, Chicago, (1933).

18. Cherpion, N., "Le (cone d'onguent), gage de survie", BIFAO 94, (1994), 79-106.

19. Daressy, G., "La Tombe d' un Mnévis de Ramsès II “, ASAE XVIII, (1919), 196-210.

20. Davies, G., The Rock Tombs of Deir El Gebrawi, Vol. II, London, (1902).

21. - The Tomb of Nefer - Hotep at Thebes, New York, (1933).

22. Davies, (Norman de Garis) ed., Seven Private Tombs at Qurnah, London, (1948).

23. de Buck, A., The Egyptian Coffin Texts, Vol. V, Chicago, (1954).

24. Demarée, R., The $3 \mathbf{x}$ i̊r $\mathrm{n}$ Ra-stelae: on Ancestor worship in Ancient Egypt, Egyptologische Uitgaven III, Leiden, (1983).

25. Desroches- Noblecourt, Ch (ed.), Un Siécle de Fouilles Francaises en Égypte, 18801980, Paris, (1981).

26. Dodson, A., "Four Sons of Horus", $O E A E$ 1, Cairo, 2001, 561-563.

27. _ " "The Canopic Equipment from the Serapeum of Memphis", in: Anthony Leahy \& John T., Studies on Ancient Egypt in Honour of H. S. Smith, London, (1999), 5975.

28. in Ancient Egypt, Cairo, (2005), 90-97.

29. El- Alfi, M., "Recherches sur Quelques Scarabées de Ramses II", JEA 58, 1972, 176181.

30. El - Banna, E., "Deux Compagnons de Métier sur une Stéle Inédite”, JEA 76, (1990), 175-178.

31. El-Saady, H., "Two Heliopolitan Stelae of the New Kingdom”, Z̈̈S 122, (1995), 101104.

32. Faird, A., "New Ptolemaic Blocks from Rub -el- Maganin-Armant", MDAIK 35, (1979), 59-74.

33. Faulkner, O., The Ancient Egyptian Coffin Texts, Aris \& Phillips, (2007).

34. $\quad$, The Ancient Egyptian Pyramid Texts, Oxford, (1969).

35. The Ancient Egyptian Book of The Dead, Cairo, (2010).

- 69 - A RAMESSIDE STELA OF THE CHANTRESS 
36. $\quad$ A Concise Dictionary of Middle Egyptian, Oxford, (1981).

37. Feucht, E., Das Grab des Nefersecheru (TT296), Mainz am Rhein, (1985).

38. Gaballa, G., "Some Nineteenth Dynasty Monuments in Cairo Museum", BIFAO 71, (1972), 129-137.

39. Gardiner, A., Hieratic Papyri in the British Museum, Vol. 1, London, (1935).

40. Egyptian Grammar, London, (1950).

41. Gauthier, H., Dictionnaire des Noms Géographiques Contenus dans Les Textes Hiéroglyphiques, Le Caire, (1927).

42. Green, L., "Hairstyles", $O E A E$ 2, Cairo, (2001), 73-76.

43. - "Clothing and Personal Adornment", OEAE 1, Cairo, (2001), 274-279.

44. Griffiths, J., "Osiris", $L \ddot{A}$ IV, (1982), Cols. 623-633.

45. Guglielmi, W., "Nebet - hetepet”, $L \ddot{A}$ IV, (1982), Cols. 362-363.

46. Habachi, L., Tell Basta, in Supplément aux Annales du Service des Antiquités de L' Égypte, Cahier No.22, Le Caire, (1957).

47. Hannig, R., Die Sprache der Pharaonen. Großes Handwörterbuch Ägyptisch-Deutsch, Mainz, (2005).

48. Hart, G., The Routledge Dictionary of Egyptian Gods and Goddesses, London, (2005).

49. .Hassan, A., La Tombe du Prince Khaemouaset (V dR no. 44), Cairo, (1997).

50. Hermann, A., Die Stelen der Thebanischen Felsgräber der 18 Dynastie, ÄF. 11, Hamburg, (1940) .

51. Hodjash, S (ed.), The Egyptian Reliefs and Stelae in the Pushkin Museum of Fine Arts, Moscow, Leningard, (1982).

52. Hölzl, R., Die Giebelfelddekoration von Stelen des Mittleren Reichs, in: Beiträge zur Ägyptologie, Vol. 10, Wien, (1990).

53. Hornung, E., The Egyptian Book of Gates, Zurich, (2014).

54. $\quad$ The Valley of the Kings, Horizon of Eternity, New York, (1990).

55. Hornung, E (ed.), The Egyptian Amduat, The Book of Hidden Chamber, Zurich, (2007).

56. Ikram, (S.) ed., The Mummy in Ancient Egypt, London, (1998).

57. Iskander, (Sameh) ed., The Temple of Ramesses II in Abydos, Vol. 1, Georgia, (2015).

58. James, (T.), The British Museum Hieroglyphic Texts from Egyptian Stelae, Vol. 9, London, (1970).

59. KaKosy, (L.), "Mnevis", L̈̈ IV, (1982), Cols. 165-167.

60. Kees, H., Der Götterglaube im Alten Ägypten, Berlin, (1977).

61. Koefoed-Petersen, O., Catalogue des Sarcophages et Cercueils Égyptiens, Copenhagen, (1951).

62. Koemoth, P., "Les Quatre Fils d' Horus sur le Pavois ou sur Le Lotus de L' Image au Rituel", OLA 191, Leuven, (2009), 381-394.

63. Lacau, P., Stèles du Nouvel Empire, in Catalogue général des antiquités égyptiennes $d u$ Musée du Caire, Nos.34001-34189, Le Caire, (1909).

64. Lange, O. (ed.), Grab- und Denksteine des Mittleren Reichs im Museum von Kairo, Vol. I, IV, Berlin, (1902).

65. $\longrightarrow$ Grab- und Denksteine des Mittleren Reichs im Museum von Kairo, Vol. II, Berlin, (1908).

66. Leblanc, Ch., Ta Set Neferou une Necropole de Thebes - Ouest et Son Histoire 1, Le Caire, (1989).

67. Leitz, Ch., Lexikon der Ägyptischen Götter und Götterbezeichnungen, Band II, OLA 111, Leuven, (2002).

68. Lexikon der Ägyptischen Götter und Götterbezeichnungen, Vol. III, OLA 112, Leuven, (2002).

69. Lexikon der Ägyptischen Götter und Götterbezeichnungen, Vol. IV, OLA 113, Leuven, (2002).

70. Lexikon der Ägyptischen Götter und Götterbezeichnungen, Vol. V, OLA 114, Leuven, (2002).

71. Lesko, S., A Dictionary of Late Egyptian, vol. 1, U. S. A., (2002). 
72. Lowle, A., "Two Monuments of Perynefer, a Senior Official in the Court of Ramesses II", ZÄS 107, (1980), 57-62.

73. Lurker, M., The Gods and Symbols of Ancient Egypt, Thames and Hudson, (1980).

74. Manniche, L., Lost Ramessid and Post-Ramessid Private Tombs in the Theban Necropolis, Copenhagen, (2011).

75. Marée, M., Egyptian Stelae in The British Museum from The $13^{\text {th }}$ to $17^{\text {th }}$ Dynasties, Vol. 1, London, (2013).

76. Martin, T., The Hidden Tombs of Memphis, London, (1991).

77. Mercer, B., The Pyramid Texts, London, (1952).

78. Mostafa, M., Das Grab des Neferhotep und des Meh ( TT 257), Mainz Am Rhein, (1995).

79. Moursi, M., “ Two Ramesside Stelae from Heliopolis”, GM 105 , (1988), 59 - 64.

80. — " Corpus der Mnevis - Stelen und Untersuchungen zum Kult der Mnevis - Stiere in Heliopolis II", SAK 14, ( 1987), 225-237.

81. Moussa, M., "Ein Denkmal zum Kult des Königs Unas am Ende der 12 Dynastie", MDAIK 31, (1975), 93-97.

82. Muhammed, M., "Two Theban Tombs Kyky and Bak -En -Amun", ASAE LIX, (1966), 170-184.

83. Müller-Wollermann, R., " Der Mythos Vom Ritus (Erschlagen der Feinde )”, GM 105, (1988), 69- 76.

84. Naguib, A., Le Clergé Féminin d'Amon Thébain á La 21 Dynastie, Leuven, (1990).

85. Onstine, L., The Role of the Chantress (Smayt) in Ancient Egypt, Toronto, (2001).

86. Petersen, K., Les Stéles Égyptiennes, Copenhagen, (1948).

87. Piankoff, A., The Tomb of Ramesses VI, Vol. 1, New York, (1954).

88. The Shrines of Tut-Ankh-Amon, New York, (1962).

89. Pischikova, E., "Representation of Ritual and Symbolic Objects in Late XXV th Dynasty and Saite Private Tombs", JARCE 31, (1994), 63-77.

90. Radwan, A., "Six Ramesside Stelae in the popular Pyramidion - Form", ASAE 71, (1987), 223-228.

91. "Darstellungen der Aufgehenden Sonne auf Einigen Stelen der Ramessidenzeit", in: Westendorf, W., Studien zu Sprache und Religion Ägyptens, Göttingen, 1984, 823-827.

92. Ranke, H., Die Ägyptischen Personennamen, vol. 1, Glückstadt, (1935).

93. Raue, D., Heliopolis und das Haus des Re, Berlin, (1999).

94. Redford, D., The Ancient Gods Speak: A Guide to Egyptian Religion, Oxford, (2002).

95. Refai, H., "Nebet - Hetepet, Iusas und Temet ", GM 181, (2001), 89-94.

96. Robins, G., "Hair and Construction of Identity in Ancient Egypt, C. 1480 - 1350 B.C.", JARCE 36, (1999), 55-69.

97. Sabbahy, K.., "The Mnevis Bull at Horizon of the Disc", in Amarna Letters 4, U.S.A., (2000), 36-43.

98. Sadek, A., Popular Religion in Egypt during the New Kingdom, Hildesheim, (1987).

99. Saleh, A, Excavations at Heliopolis, Vol. 1, Cairo, (1981).

100. Saleh, J., Les Antiquités Égyptiennes de Zagreb, Paris, (1970).

101. Scalf, F., Book of the Dead, Becoming God in Ancient Egypt, Chicago, (2018).

102. Schneider, Th., Asiatische Personennamen in Ägyptischen Quellen des Neuen Reiches, Göttingen, (1992).

103. Selim, H., "The Stela of Hr-wDw in the Cairo Museum (JE.41332)", SAK 28, (2000), 243-256.

104. Servajean, F., "Le Lotus émergeant et les Quatre Fils d' Horus, Analyse d'une métaphore Physiologique", in: S. H. Aufrére (ed.), Encyclopédie religieuse de L' Univers Végétal, Croyances Phytoreligieuses de L' Égypte ancienne, Vol. II, Montpellier, (2001), 261-297.

105. Seyfried, K., Das Grab des Amonmose (TT 373), Mainz Am Rhein, (1990).

106. Spiegelberg, W, "A Heart Scarab of the Mnevis Bull”, JEA 14, no. 1/2, (1928), 12.

107. Staehelin, E., “Tracht”, $L \ddot{A}$ VI, (1985), Cols. 726-737.

- 71 - A RAMESSIDE STELA OF THE CHANTRESS 
108. Stefanovic, D., "The Feminine Stelae of the Middle kingdom: addena The Non - Royal Women of the Middle Kingdom III: Hsyt", GM 220, (2009), 95-98.

109. Tawfik, S., "Aton Studies, 5. Cult Objects on Blocks from the Aton Temple(s) at Thebes", MDAIK 35, (1979), 335-344.

110. Teeter, E., "Female Musicians in Pharaonic Egypt", in: K. Marshall (ed.), Rediscovering the Muses: Women's Musical Traditions, Boston, (1993).

111. - Religion and Ritual in Ancient Egypt, Cambridge, (2011).

112. Tomich, A., "Late Middle Kingdom Stelae Workshops at Thebes", GM 234, (2012), 69-84.

113. Tosi, M (ed.), Stele Ealtre Epigrafi di Deir El Medina, Catalogo del Museo Egizio di Torino Nos. 50001 - 50262, Vol. 1, Torino, (1972).

114. Touraeff, B., "The Inscriptions upon the Lower Part of a Naophorous Statue in my Collection", JEA 4, no. 2/3, (1917), 119-121.

115. Valbelle, D., Témoignages du Nouvel Empire Sur Les Cultes de Satis et Anoukis à Éléphantine et à Deir El-Médineh", BIFAO 75, (1975), 123-145.

116. Vandier d' Abbadie, J., "Deux Tombes Ramessides à Gournet - Mourrai", MIFAO 87, Le Caire, (1954).

117. Vandier, J., "Iousaas et Hathor-Nébet - Hétepet", RdE 16, (1964), 55-164.

118. Ward, A., Index of Egyptian Administrative and Religious Titles of the Middle Kingdom, Beirut, (1982).

119. Westendorf, W., Ältägyptische Darstellungen des Sonnenlaufes auf der abschüssigen Himmelsbahn, $M \ddot{A} S$ 10, Berlin, (1966).

120. Wilkinson, R., the Complete Gods and Goddesses of Ancient Egypt, London, 2003.

121. Zayid, A., Trois Études d'Égyptologie, Le Caire, (1956). 


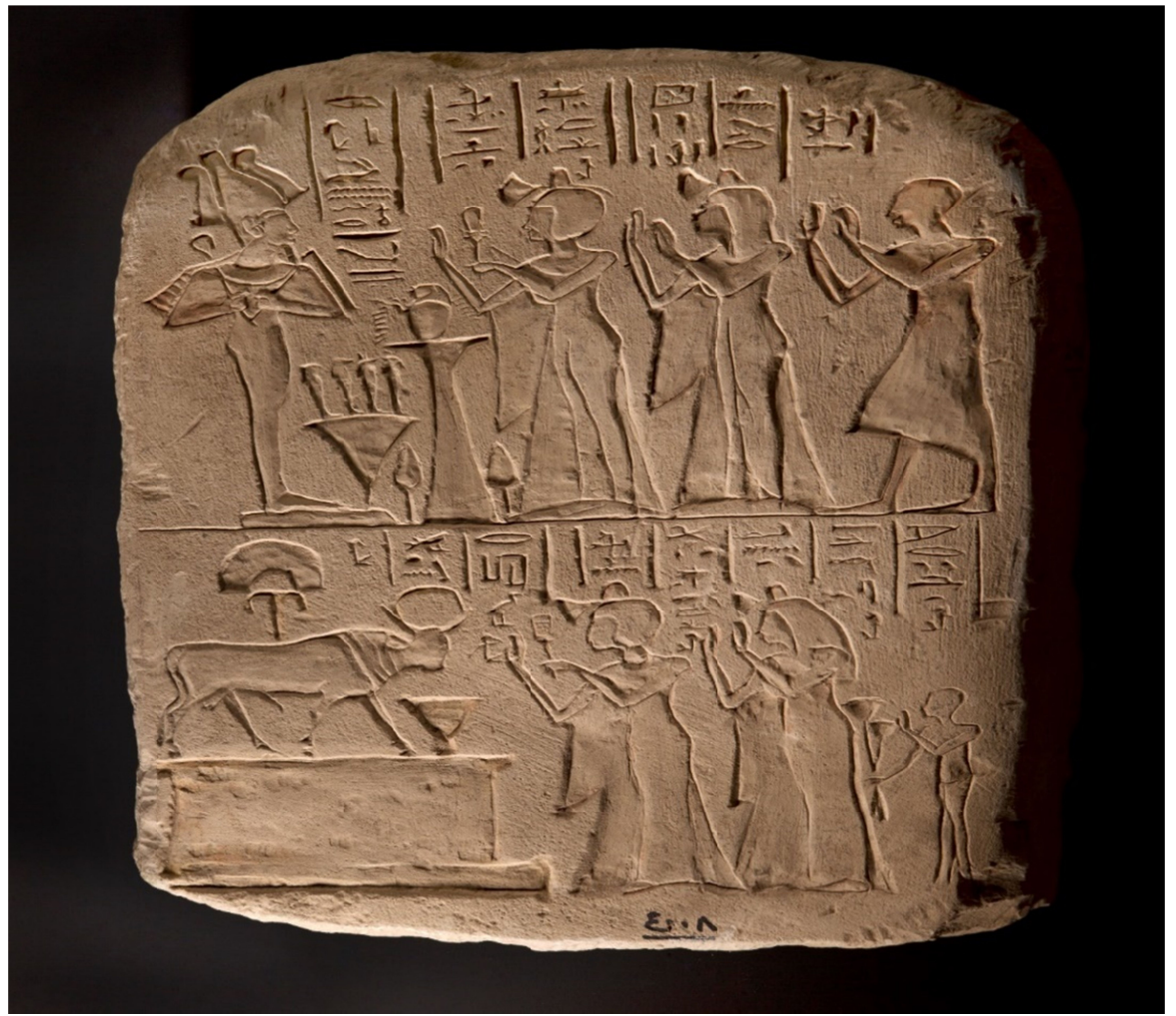

Pl.1 stela of $\underline{t} 3 w t y-n \underline{d} m$ (in Arab El-Hesn magazine at El-Mataria under registration No. 4008). Photo by Marion Wenzel

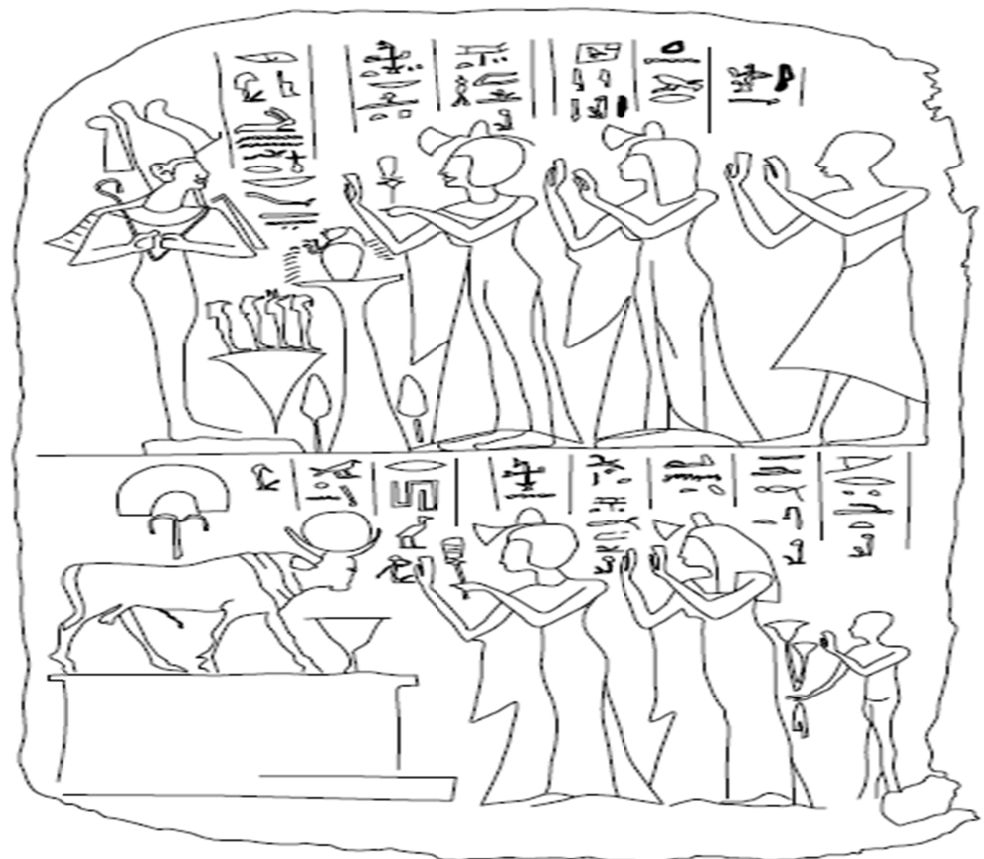

Made by Rasha Abdalhafeez. 